\title{
Comparative Studies on the Physicochemical Characteristics of Popcorn And Groundnut Flour Fermented Using Pure Strains Of Rhizopus nigricans and Saccharomyces cerevisae
}

\author{
Oyeleke, G.O. ${ }^{1}$, Lawal, R.T. ${ }^{2}$, Olagunju, E.O ${ }^{3}$. And Ojo, A. ${ }^{4}$ \\ ${ }^{1,2,3}$ S.L.T Department, Osun State Polytechnic, Iree, Nigeria. \\ ${ }^{4}$ Food Science and Technology, Osun State Polytechnic, Iree, Nigeria.
}

\begin{abstract}
Proximate, elemental and anti-nutrient composition of fermented using Sacchromyces cerevisae and Rhizopus nigricans for 72 hours and unfermented groundnut and popcorn were carried out using standard methods of analysis. The proximate analysis results showed that crude protein, fat and crude fibre increased in fermented samples. Sodium, potassium and phosphorus were also found to increase in the fermented sample while anti-nutrient was found to decrease after fermentation. The result from the research work revealed that fermentation could be a very good method of enhancing nutritional benefit of food materials and could be utilized in food formulation.
\end{abstract}

Keywords: Proximate, fermentation, groundnut, popcorn, nutritional, anti-nutrient.

\section{Introduction}

Popcorn as a common snack has a lot of flavours and advantages. It is high in carbohydrates, protein but low in fat and is therefore considered as a kind of healthy food. Without any artificial flavouring, popcorn can be considered as a natural packaging material. The internal cell structure of popcorn contains cavities inside the cell which established foamy- like structure. The structure provides protective cushioning properties similar to the function of the commercial plastic loose- fill foams. Heat is the major energy used for popping. The manufacturing process (popping) time is much shorter than the starch or cellulose based foams [1].

Furthermore, popcorn can be considered for bird feeding. Groundnut, or peanut, is commonly called the poor man's nut. Today it is an important oil seed and food crop. This plant is native to South America and has never been found uncultivated. The botanical name for groundnut, Arachis hypogaea Linn, is derived from two Greek words, Arachis meaning " legume" and hypogaea meaning "below ground", referring to the formation of pods in the soils.

There are many kinds of corn varieties in the world. The varieties are basically classified in accordance with their different kernel texture or the internal structure. In general, the distinction between corn varieties is based on the endosperm and kernel constitution, kernel colour, shape, the place where it is grown, maturity and the specific use. Similar to other corn species, popcorn kernel consist of three major structural parts: pericarp, germ and endosperm. Depending on the popcorn variety, the pericarp can be thick or thin. The pericarp is a tough protective layer surrounding the kernel and participates in the popping action. It serves as a pressure vessel enclosing and containing the endosperm. It is also an important factor in popcorn quality. The germ contributes the least to popping phenomenon. Popping does not alter the germ chemically or physically [2].

Groundnuts are important component of Nigerian diet and about 5 percent of the estimated $58.9 \mathrm{~g}$ of crude protein available per head per day is contributed by government [3]. In most of the developing countries, it provides high-quality cooking oil and is an important source of protein for both human and animal diet and also provides much needed foreign exchange by exporting the kennels and cake. One desirable change that microorganisms bring about in food is fermentation. The microorganisms responsible for fermentation of food are mainly bacteria, yeast and moulds. Of the three, yeast and bacteria are the most important.

The species of bacteria that are involved in fermentation includes lactobacillus species, streptococcus species, bacillus species, staphylococcus species etc. In the industries many microorganism are used for production of metabolites such as acids, alcohol, amino acids enzymes and antibiotics through fermentation. For food processing fermented products such as citric acids, acetic acid and glutamate are frequently used [4]; thus fermentation has the following advantages in food production; it enhances the nutritional value of a food product through increase in vitamin level, improved digestibility of food, assisting in preservation of food and also have beneficial health effects on the intestinal flora especially lactic acid bacteria .

Protein calorie malnutrition is a serious problem in the developing world, It is ironic that protein calorie malnutrition exist in areas where most of the groundnut is produced especially Africa, therefore the aim of this research work is to determine the physicochemical properties of popcorn and groundnut fermented with 
pure strains of Rhizopus nigricans and Saccharomycces cerevisae to ascertain whether there is increase or otherwise in the nutrient and anti-nutrient composition.

\section{Materials and Methods}

\subsection{Collection of Samples}

The popcorn grains and groundnut samples were purchased in Igbona market, Osogbo, Osun State and transported in polyethylene bag directly to the laboratory for examination. They were grinded into powder form and divided into two portions. A portion was fermented with pure strains of Rhizopus nigricans and Saccharomycces cerevisae and the other portion left unfermented.

\subsection{Fermentation of popcorn and groundnut.}

Three sterile conical flasks were filled with samples and labeled as follows A, B and C. The samples were measured and mixed in different proportion as follows: (A) $12.5 \mathrm{~g}$ groundnut $+7.5 \mathrm{~g}$ popcorn, (B) $10.0 \mathrm{~g}$ groundnut $+10.0 \mathrm{~g}$ popcorn and $(\mathrm{C}) 7.5 \mathrm{~g}$ groundnut $+12.5 \mathrm{~g}$ popcorn. $40 \mathrm{ml}$ of water was added to each sample in the conical flask to form damp composites. The mouths of the conical flasks were plug with cotton wool and covered with aluminum foil. They were sterilized in an autoclave at $121^{\circ} \mathrm{C}$ for 15 minutes and allowed to cool down. Sterile wire loop are used to pick colonies of Sacchromyces cerevisae and transfer into sterile water in a test tube. Sterile inoculating pin was used to pick spores of the Rhizopus nigricans and also used to inoculate the sterile water in test tube. The mixture was mixed gently. Sterile needle and syringe were used to draw $5 \mathrm{ml}$ from the inoculated water and each composite was inoculated with $1 \mathrm{ml}$ of the sterile water seeded with Sacchromyces cerevisae and Rhizopus nigricans. The composite was allowed to ferment at room temperature for 72 hours

\section{$2.3 \mathrm{P}^{\mathrm{H}}$ and titratable acidity}

Ten (10) gram of each composite before and after fermentation was mixed with $100 \mathrm{mls}$ of distilled water. The mixture was allowed to stand for 15 minutes and shaken at 5 minutes interval and filtered using whatman filter paper. The $\mathrm{pH}$ of the filtrate was then taken using a $\mathrm{pH}$ meter. The filtrate was titrated against $0.1 \mathrm{M} \mathrm{NaOH}$ to phenolphthalein end-point.

\subsection{Chemical analysis}

Moisture content was determined by drying to constant weight at $105^{\circ} \mathrm{C}$ in an oven, ash by ignition at $550^{\circ} \mathrm{C}$ in a muffle furnace, oil content by soxhlet extraction with hexane, protein by micro kjeldahl method according to AOAC, [5] methods. The mineral were analyzed by dissolving the ash in volumetric flask using deionized water with $10 \mathrm{ml}$ of $10 \%$ hydrochloric acid solution.

Sodium and potassium were determined by using a flame photometer (model 405, corning UK) using $\mathrm{NaCl}$ and $\mathrm{KCl}$ salts to prepare the standards. All other metals were determined by atomic absorption spectrophotometer (Perkin-Elmer model 403, Norwalk CT, USA). All chemicals used were of analytical grade and the minerals are reported in $\mathrm{mg} / 100 \mathrm{~g}$. Phytate and tannin were determined using AOAC, [5] methods while oxalate content was by the titrimetric method as modified by Akindahunsi and Salawu [6].

\subsection{Results}

\section{Results and Discussion}

The changes in the $\mathrm{pH}$ of the three fermented samples are shown in table 1 . The samples with equal weight of groundnut and popcorn (sample) recorded the highest $\mathrm{pH}$ of 5.6. Table 2 showed that at 72 hours of fermentation, the amount of titrable acidity in ( $\mathrm{g} / 100$ lactic acid) was also highest in sample with equal weight of groundnut and popcorn (sample $\mathrm{C}$ ). Table 3 revealed that the unfermented popcorn recorded the highest value of moisture $(10.72 \pm 0.05) \%$. This value is higher than that of unfermented groundnut $(4.49 \pm 0.01) \%$ in all the three fermented samples. The fermented sample with $7.5 \mathrm{~g}$ groundnut and $12.5 \mathrm{~g}$ popcorn (sample B) recorded the highest value of $(27.89 \pm 0.06) \%$ and is closely followed by that of unfermented groundnut with $(24.69 \pm$ $0.05)$.

The crude fat content for the three fermented sample were higher than that of the unfermented groundnut and popcorn with sample of equal weight of groundnut and popcorn having the value of $(25.76 \pm$ $0.06) \%$. The ash content obtained for unfermented groundnut was found to be the highest with $(4.54 \pm 0.04) \%$ while among the three fermented samples, sample $\mathrm{C}$ with equal weight of groundnut and popcorn recorded the highest with $3.69 \pm 0.03 \%$. High value were obtained for the fermented sample $(11.19 \pm 0.05,14.87 \pm 0.02$ and $12.85 \pm 0.05) \%$ for $\mathrm{A}, \mathrm{B}$ and $\mathrm{C}$ respectively compared to the unfermented groundnut and popcorn with $4.21 \pm$ $0.01 \%$ and $1.32 \pm 0.01 \%$ respectively.

The $\%$ carbohydrate contents of the unfermented groundnut of $61.06 \pm 0.02$ and popcorn $74.06 \pm 0.50$ were higher than the three fermented samples. The energy content of the three fermented samples with (477.10, 483.50 and 489.50$) \mathrm{Kcal} / 100 \mathrm{~g}$ for $\mathrm{A}, \mathrm{B}$ and $\mathrm{C}$ were higher than the unfermented groundnut of $437.20 \mathrm{Kcal} / 100 \mathrm{~g}$ and popcorn with $348.50 \mathrm{Kcal} / 100 \mathrm{~g}$. 
From table 4, the sodium, potassium and phosphorus contents were found to increase in fermented samples while magnesium and calcium contents were found to decrease in the fermented samples. The fermented sample recorded lower values of antinutrients compared to the unfermented groundnut and popcorn on table 5.

Table 1: Change in $\mathrm{pH}$ of the samples

\begin{tabular}{clc}
\hline Sample & Ohr & 72 hrs. \\
\hline A & 6.5 & 4.8 \\
B & 6.2 & 5.0 \\
C & 6.8 & 5.6 \\
\hline
\end{tabular}

Table 2: Titrable acidity ( $\mathrm{mg} / 100 \mathrm{~g}$ lactic acid)

\begin{tabular}{lcc}
\hline Sample & Ohr & $72 \mathrm{hr}$ \\
\hline A & 1.1 & 3.2 \\
B & 1.5 & 3.8 \\
C & 1.3 & 4.1 \\
\hline
\end{tabular}

Table 3: Proximate composition of the sample (\%)

\begin{tabular}{lccccc}
\hline Parameter & UG & UP & \multicolumn{2}{c}{ Popcorn } & Groundnut (fermented) \\
\hline & & & A & B & C \\
Moisture & $4.49 \pm 0.01$ & $10.72 \pm 0.05$ & $4.71 \pm 0.01$ & $9.68 \pm 0.05$ & $2.35 \pm 0.01$ \\
Crude protein & $24.69 \pm 0.05$ & $7.49 \pm 0.02$ & $19.96 \pm 0.05$ & $27.89 \pm 0.01$ & $13.77 \pm 0.05$ \\
Crude fat & $5.50 \pm 0.01$ & $1.01 \pm 0.01$ & $20.60 \pm 0.20$ & $24.67 \pm 0.10$ & $25.76 \pm 0.06$ \\
Ash & $4.54 \pm 0.04$ & $0.75 \pm 0.01$ & $1.88 \pm 0.02$ & $0.34 \pm 0.02$ & $3.69 \pm 0.03$ \\
Crude fibre & $4.21 \pm 0.01$ & $1.32 \pm 0.01$ & $11.19 \pm 0.05$ & $14.87 \pm 0.02$ & $12.85 \pm 0.05$ \\
N F E & $61.06 \pm 0.20$ & $74.06 \pm 0.50$ & $41.91 \pm 0.20$ & $22.55 \pm 0.05$ & $41.58 \pm 0.05$ \\
Energy * & 437.20 & 348.50 & 477.10 & 483.50 & 489.50 \\
\hline
\end{tabular}

Key: UG- unfermented groundnut, UP- unfermented popcorn, A- $12.5 \mathrm{~g}$ groundnut $+7.5 \mathrm{~g}$ popcorn flour (fermented), B $-7.5 \mathrm{~g}$ groundnut $+12.5 \mathrm{~g}$ popcorn flour (fermented), C $-10.0 \mathrm{~g}$ groundnut $+10.0 \mathrm{~g}$ popcorn flour (fermented), *Kcal/100g (calculated), NFE - Nitrogen free extractive, $\mathrm{n}=2$

Table 4: Mineral composition $(\mathrm{mg} / 100 \mathrm{~g})$

\begin{tabular}{lccccc}
\hline Element UG & UP & \multicolumn{4}{c}{ Popcorn + Groundnut (fermented) } \\
$\mathrm{Na}$ & $189.20 \pm 0.01$ & $103.89 \pm 0.05$ & $350.00 \pm 0.05$ & $\mathrm{~A}$ & $\mathrm{C}$ \\
$\mathrm{K}$ & $152.00 \pm 0.02$ & $112.01 \pm 0.01$ & $317.00 \pm 0.20$ & $384.00 \pm 0.50$ & $546.00 \pm 0.06$ \\
$\mathrm{Mg}$ & $101.20 \pm 0.02$ & $89.13 \pm 0.03$ & $34.00 \pm 0.50$ & $39.00 \pm 0.10$ & $36.00 \pm 0.20$ \\
$\mathrm{Ca}$ & $75.10 \pm 0.10$ & $60.00 \pm 0.05$ & $23.00 \pm 0.10$ & $23.00 \pm 0.10$ & $22.00 \pm 0.50$ \\
$\mathrm{P}$ & $380.00 \pm 0.50$ & $300.00 \pm 0.50$ & $308.00 \pm 0.05$ & $380.00 \pm 0.25$ & $350.00 \pm 0.10$ \\
$\mathrm{n}=2$ & & & &
\end{tabular}

Table 5: Anti-nutrient composition $(\mathrm{mg} / \mathrm{g})$

\begin{tabular}{llcccc}
\hline Parameter & UG & UP & \multicolumn{2}{c}{ Popcorn + Groundnut (fermented) } \\
\hline & & & A & B & C \\
Phytic acid & $1.35 \pm 0.05$ & $1.25 \pm 0.02$ & $0.58 \pm 0.02$ & $0.82 \pm 0.02$ & $1.15 \pm 0.05$ \\
Oxalate & $2.94 \pm 0.02$ & $2.70 \pm 0.05$ & $2.16 \pm 0.01$ & $2.17 \pm 0.01$ & $2.52 \pm 0.02$ \\
Tannin & $2.50 \pm 0.02$ & $2.58 \pm 0.01$ & $1.95 \pm 0.01$ & $0.95 \pm 0.02$ & $2.44 \pm 0.04$ \\
n=2 & & & & & \\
\hline
\end{tabular}

\subsection{Discussion}

During the fermentation process, the $\mathrm{pH}$ reduced gradually as the fermentation progressed. It has been reported elsewhere that during brine fermentation of vegetable, bacteria of lactobacillus group convert the natural sugar present in the vegetable to lactic acid thereby decreasing the $\mathrm{P}^{\mathrm{H}}$ with liberation of carbon dioxide on the surface of the brine solution. Equal weight of groundnut and popcorn fermented at 72 hours showed an increase in titrable acidity compared to the other two samples. At 0 hour, it was sample B with higher weight of popcorn (7.5g groundnut $+12.5 \mathrm{~g}$ popcorn) that gave increase titrable acidity. Oyewole and Ogundele, [7] attributed the increase in titrable acidity to the production of organic acids during the fermentation.

Moisture content of the unfermented groundnut and popcorn are $(4.49 \pm 0.01 \%)$ and $(10.72 \pm 0.05 \%)$ respectively. The values obtained for the three fermented samples are lower than $10.72 \pm 0.05 \%$ recorded for unfermented popcorn. The value reported here for unfermented popcorn was in line with $10.77 \%$ reported for IPM 1006 variety of millet [8]. The value obtained for the three fermented samples were however lower than the $10 \%$ moisture content limit to recommend for storage stability of flours. 
The crude protein content of sample with ( $7.5 \mathrm{~g}$ groundnut $+12.5 \mathrm{~g}$ popcorn) recorded the highest value while unfermented popcorn had the least value of $7.49 \pm 0.02 \%$. The decrease in the protein content of sample A (12.5g groundnut $+7.5 \mathrm{~g}$ popcorn) and sample C $(10 \mathrm{~g}$ groundnut $+10 \mathrm{~g}$ popcorn $)$ compared to $(24.69 \pm 0.05) \%$ for unfermented groundnut is similar to the work of Oladele and Oshodi, [9] who recorded decrease in value for fermented Jatropha cathatica and Jatropha curcas. Our result is similar to the work of Eze and Ibe, [10] who worked on fermentation of B. eurycoma where a decrease in protein content from $3.35 \%$ to $2.29 \%$ was reported. The decrease in crude protein of the fermented flours may be due to the fact that the activities of microorganisms may have led to the broken down of amino acid with liberation of ammonia [9].

Increases in crude fat were observed for the fermented samples compared to the unfermented sample. This observation is contrary to the findings of Eka, [11] who reported decrease in crude fat content of locus beans after fermentation. The ash contents of fermented samples are low compared to that of unfermented groundnut with $4.54 \pm 0.04 \%$. The decrease in ash contents may be due to the activities of fermentation microorganisms. The crude fibre values surprisingly increased for the fermented samples. The reason for the unexpected increase in fibre content for the fermented samples may also be due to the activities of microorganisms. The fermentation process involves the conversion of materials to the peculiar needs of microorganism which include the bacterial cell wall because the microorganisms were not separated from the biomass, the increase in fibre could be due to conversion of such materials to peptidoglycan by the fermenting microorganisms [10]. Carbohydrate contents also decreased after fermentation, this is obviously due to the fact that they were used up as the source of energy during fermentation by the microorganisms. The energy contents in $(\mathrm{Kcal} / 100 \mathrm{~g})$ of fermented samples also increased and this could be as a result of the microbial activities as explained earlier.

The results of the mineral analysis for the unfermented and fermented samples are shown on table 4 , these results showed that fermentation increases the content of some vital elements such as sodium, potassium and phosphorus. This observed increase in mineral composition may be due to the contribution from fermentation microorganisms. The mineral content of the unfermented and fermented samples were higher than value reported for African Oil Bean (Pentaclethra marcrophylla) by Odoemelam, [12]. Decreased values were however obtained for magnesium and calcium in the fermented samples. The reduction in the antinutrients content in the fermented samples compared to the unfermented samples could be as a result of microbial activities. The result obtained here seems to be contrary to the findings of Oladele and Oshodi, [9] that reported increase in phytate and tannin contents of Jatropha spp after fermentation.

\section{Conclusion}

It can be concluded that nutritional benefit of groundnut and popcorn flour can be enhanced when fermented. Fermentation from this research work has been able to increase protein, fat, energy, Na, K and P contents with corresponding decrease in anti-nutrient content and therefore could be used to enhance better quality in food materials.

\section{References}

[1] B. Livesey, Hold the butter and salt. Profit, Vol. 1, 1990, 35

[2] R.C. Hoseney, K. Zeleznak, A. Abdurahman, Mechanism of popcorn popping. J. of Cereal Sci. 1, 1983, $43-52$.

[3] G.O. Abulu, An economic analysis of groundnut production in Northern Nigeria. In proceedings of the National seminar on groundnut production, Kano, Nigeria, 1978, 83-90

[4] P. Campbell, Effect of microorganisms on the nutrient status of locust beans. J. Food Chemistry, 5, 1978, $201-203$.

[5] AOAC, Association of official analytical chemists, official methods of analysis $\left(15^{\text {th }}\right.$ edition, Washington, D.C. 1990).

[6] A.A. Akindahunsi, S.O. Salawu, Phytochemical screening and nutrient-antinutrient composition of selected tropical green leafy vegetables. African Journal of Biotechnology. Vol. 4(6), 2005, 1684-1692..

[7] Oyewole, O.B. and Ogundele, S.L. (2001). Effect of length of fermentation on the functional character of fermented cassava fufu; J. Food Technol. Afri. Vol .6(2), 2001, 38-40

[8] G. Ravindran, Studies on millets: Proximate composition, mineral, phytate and oxalate contents. Food Chem. 39, 1991,99 - 107.

[9] E.P. Oladele, A.A. Oshodi, Effect of fermentation on some chemical and nutritive properties of Berlandier nettle spurge (Jatropha cathartica) and physic nut (Jatropha curcas). Pakistan Journal of Nutrition, 7(2), 2008, 292-296.

[10] S.O. Eze, O.J. Ibe, Effect of fermentation on the nutritive value of B. Eurycome "Achi'. J. Chem.. Soc. Nig. No 1, 2005 , 10-15.

[11] O.U. Eka, Effect of fermentation on the nutrient status of locust beans. Food chem., 5, 1980, 305-308.

[12] S.A. Odoemelam, Proximate composition and selected physicochemical properties of the seeds of African oil Bean (Pentaclethra marcrophylla). Pak. J. Nutr. 4, 2005, 382-383. 